\title{
It Is A Small World After All: Teaching Business Ethics In A Global Environment
}

Connie B. Budden, Southeastern Louisiana University, USA

Michael C. Budden, Southeastern Louisiana University, USA

\begin{abstract}
Increasingly, managers and employees are facing ethical issues when conducting business in the global marketplace. Business educators attempting to teach appropriate ethical behavior and develop skills for dealing with complex ethical situations need to incorporate realistic case scenarios to challenge students. Such cases should appropriately address personal, corporate and international and cultural issues students are likely to face. This paper presents realistic cases that have been used to teach ethical decision-making in international business classes.
\end{abstract}

\section{INTRODUCTION}

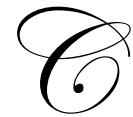

ase analyses are widely used in management and international management education. In fact, it would be a rare, if not a unique, educational program that did not incorporate some case analyses into management and international management education. In the 1980s, two major disasters, and the responses of those involved, brought attention to the importance of international ethics. The Chernobyl nuclear disaster in the Ukraine and the Bhopal disaster in India alerted the international community of the importance of ethics in an international setting.

More recent newsworthy issues have arisen, including Citigroup's involvement in the Enron bankruptcy and the large number of rollovers of Ford's Explorer vehicles. The Deepwater Horizon catastrophe and resulting oil spill in the Gulf of Mexico presented many with opportunities to exercise and test new ethical standards. Arguably, the manner in which these issues were dealt resulted in increased interests in international ethical behavior and standards. Indeed, some will argue that managers in these and other efforts have increased the amount of oversight that many businesses are being subjected to in order to assure decisions are made in a culturally and environmentally aware manner.

As Wild, Wild and Han (2010) explain, international ethics are complicated by unfamiliar cultural rules with which legal systems are inadequate to effectively deal. Peng (2009) believes that ethics is an important part of the informal institutions, but also reflects the formal laws and regulations of society. There is a substantial overlap between what is ethical and what is legal. Indeed, Peng mentions many companies have instituted a code of conduct as a set of guidelines to help management make better ethical decisions.

Due to recent ethical disasters in the US and internationally, Comegys (2010) emphasizes the importance of colleges and universities preparing the next generation of business leaders to face complex ethical issues. Further, Comegys found that ethical education and university climate played an important role in impacting students' attitudes and business ethics. Colleges of business have not sat idle. Many have incorporated ethics in their curricula. For instance, Niles (2006) mentions that Concord University implemented a required business ethics course in response to recent business ethical lapses. For business schools seeking accreditation, or to maintain their accreditation by AACSB, accreditation standards require schools to incorporate the issue of ethics in their curricula.

In looking at the factors that impact ethical behavior of college students, Joseph, Berry, and Deshpande (2010) found that ethical behavior of peers, GPA and gender impacted ethical behavior. Female students were found to be more ethical than their male counterparts. This study puts forth the importance of peer influence, 
suggesting ethical training should incorporate more theoretical exercises. Colleges need to include role-modeling exercises to improve ethics training in classrooms.

Budden, et. al (2010) suggest the importance of using realistic scenarios to improve distance learning in Latin America. Surely, the use of case scenarios involving situations students may face will improve their chances of making informed choices, regardless of where they are located. According to Firmin, et. al (2009), employers expect new employees to possess a number of character training experiences, including those obtained through higher education, before commencing employment. Again, the use of case scenarios will only improve the learning environment, even when the complex subject of ethics is involved.

\section{THE SITUATION AT HAND}

Business faculty members at Southeastern Louisiana University are expected to incorporate the concept of business ethics in most classes. Professors are free to decide how to incorporate ethics in their courses, but they must do so in order for the college to demonstrate its commitment to accreditation standards and its commitment to producing students with ethical decision-making tools. For the purpose of this paper, the required international business course incorporates a history of international ethical issues and current ethical issues faced by international businesses and methods for improving ethics in organizations.

International business includes multiple realistic case scenarios that students have to analyze and address. Students who have been assigned groups are presented with a number of short ethical dilemmas. Students are expected to discuss each case with group members and address the ethical issues of each case and determine whether or not the course of action is ethical. Once groups have completed their analyses and discussions, the instructor leads a class discussion with each group defending their actions.

A variety of original short cases have been used. Each case is distributed to students. Cases have changed over the years but have dealt with a variety of ethical situations including bribery, safety issues, environmental issues, health issues, and potential disasters. The cases and all firms/individuals mentioned were (and are) fiction.

1. A vendor flies in from Panama every six months. While in town, he takes you, the company's purchasing manager, to lunch. Lunch usually costs about $\$ 40$, plus tips. During these meetings, you discuss your company's needs and the vendor discusses how his firm's new products and services could satisfy those needs. The two of you also discuss pending changes in your needs that may require the vendor's firm to respond quickly. Is this okay?

\section{$\underset{\text { Yes }}{\mathrm{No}}$}

2. You go to a country where bribery is widespread and widely accepted. You desire to open a business there to take advantage of favorable wage rates, government incentives and taxes. Normally, it takes six months to a year to get the license. You give $\$ 200$ and a bottle of liquor to a government clerk asking the clerk to speed up your license application. You receive the approved license the next day. Is this okay?

\section{$\underset{\text { Nos }}{\longrightarrow}$}

3. You visit a country noted for its rain forests and wildlife diversity. Among the wildlife is a spotted mole snake that is considered threatened but not yet endangered. Its habitat is disappearing as the rain forests are cut down to make way for farms. While shopping, you notice that some of the local artisans have made boots from mole snakes. The boots are beautiful and you are told they are quite durable. They are amazingly inexpensive. You decide to buy a pair. Is this okay?

Yes No 
4. You are on a hike deep in a rain forest. You took along energy bars and a bottle of water for the walk. There are no trashcans in the forest. After eating a couple of bars and drinking the water, your guide tells you it is okay to throw your trash on the ground as eventually the paper and plastic will rot and nobody will ever see them anyway. Is this okay?

\section{$\underset{\text { No }}{\text { Yes }}$}

5. Your division needs a new computer system that will cost $\$ 1,400,000$. There are three viable vendors who can deliver the hardware and appropriate support. Two of the vendors come to the plant and discuss their systems and the support that would follow. They both mention that their systems are currently in place in other plants and that if you could travel to those locations, they would arrange demonstrations. The third vendor offers to send its corporate jet to pick up you and your immediate staff and fly you to San Jose, Costa Rica, where one of its systems is located. They will provide rooms, demonstrate the system, and arrange for you and your staff to sightsee before flying you back. Is this okay?

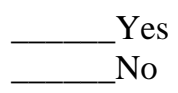

6. You are the president of a large, vertically integrated producer of prepared food products. Your company is considering opening a production facility in a small African country where famine and shortages of food recur with alarming regularity. Your firm plans to purchase a large tract of land to grow high-yield soy and corn crops to enable your new production plant to prepare your final product - a high protein, high vitamin flour that can be used to address recurring famines and hunger. To support local self-sufficiency, your firm will subsidize area farmers who agree to grow the crops and will buy their produce at market prices. If your plan succeeds, the price of the flour will be affordable to the great majority of the country's people. To acquire the land and establish the plant, a variety of licenses and permits are required. A senior government official approaches you privately and requests a payment of $\$ 100,000$ cash to quickly authorize the project. Is this okay?

\section{- Yes}

\section{TEACHING NOTES AND SUGGESTIONS}

Students are broken up into groups of three or four. Each group is given a copy of the short cases. Group members identify and discuss the ethical issues of each case and determine an appropriate course of action. Groups are required to discuss why they believe their chosen course of action is ethical or not.

After each group has a chance to arrive at a decision and reasoning to pursue their course of action, the professor leads the class discussion with each group defending their actions. Most discussions focus on the legal implications as well as the ethical issues. The professor makes sure to indicate any laws that may impact the issue, but it is the ethics that are of concern. The differences in what is legal and what is ethical are contrasted at length. Also, international students in the class are asked to express how they feel their country's people would respond to the scenarios presented.

In one such discussion about littering, a student from New Zealand was asked about littering in her country. She said she was amazed at the amount of litter on the streets of the US. She mentioned that people in her country took pride in their country and did not litter like Americans. Needless to say, this comment caused quite a discussion as to the ethics of littering. Indeed, the discussion that ensued was just the type of discussion the cases are expected to create. 


\section{FINDINGS AND FINAL COMMENTS}

Students have been surveyed after the administration of these cases to ascertain their feelings about the scenarios' ability to present ethical issues. Students indicated they feel these short cases present realistic issues they are likely to face. Students report they appreciate the length of the cases and their ability to present a significant ethical dilemma in a short format.

It should be noted that students have not always agreed on the correct course of action. Indeed, it is the hope of the professor that students will not agree on all courses of action, as it is the disagreement that allows for an in-depth look at the issues involved.

Note: Individuals and organizations, and the specifics of the cases presented, are fictional.

\section{AUTHOR INFORMATION}

Michael C. Budden is the Mayfield Professor of Marketing at Southeastern Louisiana University. His research interests include consumer behavior, retailing and commercial law.

Connie B. Budden is an instructor of Management at Southeastern Louisiana University. Her research interests include human resource development, leadership and international management.

\section{REFERENCES}

1. Budden, C.B.,Brenes, L., Baraya, A.R, and Budden, M.C. (2010, May). Inclusion Needs of 3.0 Students In Latin America. Comtemporary Issues In Education Research, 3(5), 1-8.

2. Comegys, C. (2010, June). The Impact of Religiously Affiliated Universities and Courses In Ethics and Religious Studies On Students' Attitude Toward Business Ethics. Contemporary Issues In Education Research, 3(6), 35-44.

3. Firmin, M., Proemmel, E., McDivitt, S., Evens, J. and Gibbs, L., (2009, January/February). The Role Of Character In The Hiring Process: A Pilot Study Survey Of College Seniors' Potential Employers. American Journal of Business Education, 2(1), 37-45.

4. Joseph, J., Berry, K. and Deshpande, S., (2010, May). Factors That Impact The Ethical Behavior Of College Students. Contemporary Issues In Education Research, 3(5), 27-33.

5. Niles, N. J. (2006, October). Business Ethics Education: One Management Educator's Perspsective. Journal of College Teaching and Learning, 3(10), 71-78.

6. Peng, M.W., (2009). Global Business, 69-73. South-Western / Cengage Learning. Mason, OH.

7. Wild, J. J., Wild, K. L. and Han, J.C.Y. (2010). International Business The Challenges Of Globalization $5^{\text {th }}$ Edition, 100-106. Prentice-Hall 